\title{
SOCIABILIDADES FAMILIARES E LIBERDADE: relações interpessoais no pós-abolição
}

\author{
Rogério da Palma* \\ Oswaldo Truzzi**
}

\begin{abstract}
De acordo com a historiografia sobre o fim do escravismo, os vínculos sociais constituídos ainda no cativeiro foram essenciais para os libertos na construção da trajetória que levava da escravidão à liberdade. Tomando como foco o município de São Carlos, o artigo analisa as tensões presentes nas relações interpessoais tecidas entre negros, de um lado, e fazendeiros e pequenos proprietários rurais, do outro, durante o período pós-emancipação. Por meio da leitura de dois inquéritos policiais da época, percebeu-se que os códigos morais orientadores dessas sociabilidades eram (re) construídos, por parte dos afro-brasileiros, a partir da articulação de duas experiências vivenciadas: a migração interna de escravos, ocorrida durante as últimas décadas da escravidão, e o processo de redefinição de determinadas hierarquias sociais firmado no período pós-abolição. Esses códigos morais, por sua vez, acabavam por delimitar uma visão específica acerca das sociabilidades familiares.

PALAVRAS-CHAVE: Pós-abolição. Oeste paulista. Negros. Economia cafeeira. Relações interpessoais.
\end{abstract}

\section{INTRODUÇÃO}

Já há algum tempo, a aplicação do conceito de redes sociais se estabeleceu como uma temática muito cara aos estudos migratórios. Sucedendo e ampliando a noção de cadeias migratórias, as abordagens que utilizaram as redes sociais como eixo central de seus argumentos demonstraram como informações e demais recursos advindos de relações interpessoais (materiais ou estritamente simbólicos) são fundamentais em múltiplos processos migratórios. De acordo com elas, a decisão de emigrar, a escolha do destino e a inserção no mercado de trabalho da sociedade receptora, temas clássicos dentro do campo de estudos acerca das migrações, seriam concretizadas por meio da operacionalização dos recursos disponibilizados

\footnotetext{
* Doutorando em Sociologia na Universidade Federal de São Carlos (UFSCar.). Bolsista da FAPESP.

Via Washington Luís Km 235. Monjolinho. Cep 13565905. Caixa-postal: 676. São Carlos - SP - Brasil. rog.cs@hotmail.com

* * Doutor em Ciências Sociais. Professor associado da UFSCar. nos Programas de Pós-Graduação em Ciências Sociais e Engenharia de Produção. Pesquisador do CNPq. truzzi@ufscar.br
}

pelos laços sociais de cada sujeito ou família. De um modo geral, pode-se afirmar que, ao instituir as dinâmicas de sociabilidade como foco de análise, a ideia de redes sociais proporcionou uma perspectiva mais relacional para os estudos sobre o fenômeno migratório e suas diversas variáveis, o que a alçou a uma posição de destaque entre sociólogos, antropólogos e historiadores. Tornou-se comum, nesse sentido, a citação de uma frase elaborada por Charles Tilly, segundo a qual "não são os indivíduos que migram, mas sim as redes"; são elas que se transplantam e se remodelam a partir dos deslocamentos. Claro que indivíduos migram, às vezes, sozinhos, mas o fazem como participantes de um processo social que se estende para além deles próprios. ${ }^{1}$

O objetivo deste artigo não é propriamente realizar uma análise de redes. Não se pretende esboçar nenhum tipo de levantamento pautado pela metodologia de redes sociais. Almeja-se, na verdade, utilizar algumas das reflexões tecidas pelos

${ }^{1}$ Para uma análise mais completa acerca das aplicações do
conceito de redes sociais dentro dos estudos migratóriconceito de redes sociais dentr
os, consultar Truzzi (2008). 
estudos que fazem uso dessa definição, sobretudo aquelas referentes à atuação das relações interpessoais nos deslocamentos populacionais, para pensar o impacto de um dado processo migratório na dinâmica de sociabilidade familiar de uma determinada conjuntura. O processo migratório em questão representa, por sua vez, um caso bem específico. Trata-se da saída compulsória de escravos de diversas regiões do país, principalmente do Nordeste, rumo às lavouras do Sudeste, a partir de 1850. Essa data marca o fim definitivo do comércio de cativos na rota África-Brasil, o que fez com que boa parcela das lavouras cafeeiras localizadas no Rio de Janeiro e em São Paulo, em plena expansão nessa época, recorresse ao mercado interno de escravos. Nesse sentido, busca-se, por meio do exame de dois inquéritos policiais, analisar algumas das tensões e ambiguidades presentes nas relações interpessoais tecidas por dois ex-escravos que migraram forçados para São Carlos, município situado no oeste paulista cafeeiro, a partir da segunda metade do século XIX. A ambiguidade decorre do fato de que, por um lado, as redes de relações pessoais permitiam efetivamente a adoção de certas estratégias familiares. Entretanto, por outro, essas mesmas relações colocavam em xeque a lógica familiar inerente a tais estratégias. Ao manterem laços de compadrio ou afinidade com fazendeiros ou pequenos proprietários, negros e negras acabavam por colocar em disputa referenciais hierárquicos anteriormente circunscritos às interações familiares. As disputas em torno desses referenciais, por seu turno, exacerbam a existência de códigos morais na mediação dessas relações, os quais, muitas vezes, estavam implicitamente ligados à questão da redefinição do estatuto social dos ex-escravos durante o período pós-abolição e, concomitantemente, às consequências trazidas pelo processo migratório que levou um grande contingente de escravos ao Sudeste. Com isso, pretende-se explorar um pouco mais as formas de controle e as hierarquias que circulavam pelos recursos propiciados por esses laços sociais, bem como a relação do processo migratório abordado com as disputas travadas durante o período pós-emanci- pação, pela construção de novos códigos morais para os vínculos interpessoais.

\section{O COMÉRCIO INTERPROVINCIAL DE ESCRA- VOS E SEUS IMPACTOS NA DINÂMICA DE SOCIABILIDADE DA ECONOMIA CAFEEIRA}

Como foi dito anteriormente, a metade do século XIX foi o momento em que o tráfico de escravos africanos alcançou o seu fim definitivo, justamente o mesmo período em que a economia cafeeira do Sudeste estava em franca ascensão. O comércio interno de escravos cresceu, a partir de então, de forma exponencial. Milhares de cativos foram arrancados novamente dos lugares onde estavam fixados e trazidos para um destino que não conheciam. Estima-se que entre 200 e 250 mil escravos foram relocados para as províncias do Sudeste entre 1850 e 1888 (Graham, 2004, p. 296; Slenes, 2004, p.329-330). Durante muito tempo, no entanto, a historiografia brasileira sobre a escravidão não se deteve sobre os detalhes desse fluxo, preferindo se concentrar na compreensão da dinâmica migratória estabelecida a partir do tráfico de escravos da África para o Brasil. ${ }^{2} \mathrm{O}$ enfoque pairava sobre a forma como uma suposta "cultura africana" ${ }^{\text {" }}$ - tradições religiosas, relações de parentesco, hábitos culinários, práticas de trabalho etc. - teve de ser ressignificada a partir da experiência de travessia do Atlântico. Ou então como essa "cultura" trouxe impactos para a sociedade receptora e influenciou na forma como senhores e demais homens livres pensavam e se relacionavam com os cativos. Aos poucos, no entanto, vários historiadores perceberam a importância dos deslocamen-

Para estudos com diferentes perspectivas teóricas, metodológicas e temporais sobre o tráfico africano de escravos para o Brasil, ler, entre outros: Alencastro, 2000; Florentino, 1997; Klein, 1978; Reis, Santos, Carvalho, 2010 3 São diversas as orientacões presentes nos estudos acerca da importância das influências africanas para a vivência da escravidão no Brasil. Alguns estudos estão pautados por uma concepção estanque de cultura, segundo a qual ela seria uma totalidade bem definida e autocentrada, enquanto estudos mais recentes optam por uma perspectiva mais relacional, percebendo o caráter contingente e negociável que adquire a apropriação de determinados sinais diacríticos 
tos internos de escravos, com especial atenção ao grande movimento que se desenvolveu em direção ao Sudeste durante a segunda metade do século XIX.

Surgiram, ao longo dos anos, vários estudos que apontavam as tensões trazidas por esse fluxo de pessoas e suas consequências para dinâmica de sociabilidade das fazendas cafeeiras paulistas e cariocas. Aqueles que analisaram toda a dinâmica do comércio interno de escravos não são reticentes em afirmar a contrariedade dos escravos envolvidos nas negociações (Castro, 1995; Machado, 1987; Chalhoub, 1990; Graham, 2002; Slenes, 2004). As separações familiares e afetivas foram constantes, e a mudança para um lugar desconhecido causava uma série de inquietações. Nesse ponto, cabe ressaltar aqui o fato de a grande maioria dos cativos que migraram para as lavouras do Sudeste não ser proveniente de grandes fazendas, mas sim de pequenas propriedades rurais, ou então das cidades. Segundo a historiografia, os maiores proprietários de escravos, como é o caso, por exemplo, dos senhores de engenho do Recôncavo Baiano, conseguiram segurar boa parte de seus escravos mesmo com a queda das exportações verificada a partir da segunda metade do século XIX. Foram aqueles senhores com poucos recursos que tiveram de se desfazer de seus escravos e vendê-los para as então promissoras fazendas de café do Sudeste, não sem antes repassá-los para uma cadeia de intermediários que lucrava com esse comércio. ${ }^{4}$ Não foram poucos, por sua vez, os escravos que se mostraram inconformados com uma mudança tão abrupta e repentina em suas vidas. Os relatos de fugas e de outras formas de relutância quanto a essa migração forçada - algumas das quais adquiriram um caráter de violência física contra senhores e os intermediários do comércio - são constantes entre as pesquisas já realizadas sobre o tema (Castro, 1995; Machado, 1987; Chalhoub, 1990). O deslocamento para uma fazenda de café, situada em um local desconhecido, não era visto com bons olhos pelos cativos.

${ }^{4}$ Uma descrição bem detalhada das condições e dos procedimentos sob os quais se efetivou o comércio de cativos para o Sudeste está em Graham (2002).
Para aqueles que realmente migraram, há constatações de que as situações não foram das melhores. Para alguns autores (Couceiro, 2003), a vinda de escravos para o Sudeste representa um momento de inflexão no que se refere à formação de redes de sociabilidades entre os cativos. Esse trânsito de escravos trouxe consigo a fixação de diferenças entre os escravos estabelecidos e os recém-chegados, uma vez que esses últimos se depararam com redes de sociabilidade estabelecidas anteriormente à sua vinda. Os escravos mais antigos haviam construído suas próprias regras de convívio, assim como já estavam mais próximos dos códigos morais que estruturavam as relações entre senhor e escravos. Para aqueles que estavam chegando, esse era um momento de ressignificação dos vínculos relacionais e identitários. A experiência da migração sugere uma reinvenção das identificações e dos laços sociais; tudo isso a partir do contato com novas formas de trabalho e com indivíduos desconhecidos. A formação de alianças entre os escravos adquiriu, desse modo, um caráter muito diverso e complexo, variando de acordo com as leituras que se faziam das normas de convivência previamente estabelecidas.

Essa divisão construída a partir do tráfico interprovincial entre os escravos novos e os já estabelecidos era decisiva para a constituição de relações de parentesco, como o casamento, por exemplo, e também para a possibilidade de se firmar relacionamento com outros cativos e com as demais pessoas livres. De acordo com a historiografia, a construção desses vínculos era algo que estava mais ao alcance daqueles escravos que estavam fixados nas fazendas há mais tempo. Tais laços sociais, por seu turno, aumentavam as chances de morar em uma casa própria, a qual era um dos quesitos para serem obtidos determinados direitos informais, dentre eles o usufruto de uma parcela de terra. Não eram apenas questões materiais, entretanto, que norteavam essa divisão, mas também formas simbólicas de distinção. Como apontou Monsma,

[...] é muito provável que às diferenças materiais entre escravos estabelecidos e novos correspondiam distinções simbólicas, com os mais estabeleci- 
dos reivindicando maior reconhecimento e respeito entre escravos e negros livres do que os recém-chegados (2005, p. 105).

A designação “escravo novo”, por exemplo, ganhou novos significados a partir da segunda metade do século XIX: não se referia mais aos cativos recém-capturados na África e trazidos para o Brasil, mas aqueles que chegaram de outras regiões para as fazendas do Sudeste. Esse termo era empregado, geralmente, quando um escravo não realizava corretamente o seu trabalho, o que demonstra a dificuldade que muitos dos "escravos novos" sentiram quanto à adaptação a novos ritmos e formas de trabalho. Devido a isso, portanto, boa parte da historiografia cita os escravos transacionados como os mais propensos a se envolverem em conflitos violentos, crimes, revoltas etc.

De acordo com a historiografia, a maioria dos escravos enviados para as lavouras do Sudeste era formada de homens com idade para o trabalho. ${ }^{5}$ A adaptação às redes familiares e de amizade já existentes nas senzalas, além das novas relações de trabalho, não deixaram de ser traumáticas e terminaram, não raras vezes, em tragédias. Ao estudar a trajetória de famílias escravas situadas em Campinas, um dos centros da economia cafeeira paulista, Cristiany Rocha (2004, p. 156) faz o seguinte relato sobre os cativos que foram trazidos de outras regiões.

O desrespeito aos laços de família e de parentesco, a imposição de uma rotina de trabalho na lavoura de café à qual a maioria deles não estava acostumada e, por fim, os castigos excessivos, que eles percebiam como injustos e ilegítimos, foram os principais elementos que configuraram a trajetória daqueles enraizados. Assim como Bráulio, Justina, José e Basílio, muitos outros escravos cometeram crimes violentos em resposta a esses efeitos do tráfico em suas vidas.

Isso não quer dizer, todavia, que não havia presença de mulheres. Segundo estatísticas apresentadas por Richard Graham (2004, p. 300), na década de 1870, desembarcavam uma média anual de 350 escravas no porto do Rio de Janeiro, principal entreposto do comércio interprovincial de escravos. A maior parte delas iria trabalhar como domésticas, enquanto outras eram empregadas como prostitutas na própria cidade do Rio de Janeiro. O que parece certo, todavia, é que tanto escravos como escravas eram negociados de forma separada, ou seja, eles eram separados de seus laços sociais quando vendidos para o Sudeste.
Ações violentas contra senhores, feitores, administradores e outros escravos parecem ter sido algo constante dentro da trajetória de vários dos escravos que vieram trabalhar nas regiões cafeeiras. Como argumentaram alguns autores (Castro, 1998, p. 178; Rocha, 2004, p. 156), o que estava em disputa, nesses conflitos, eram as diferentes percepções acerca do cativeiro: os cativos migrados vieram de outra realidade escravista e não aceitavam as novas normas de convívio, as novas relações de trabalho e as formas como eram aplicadas as punições nas fazendas do Sudeste. O desfecho violento desses embates era o resultado das negociações em torno dos códigos sociais que balizavam as interações entre senhores e escravos recém-chegados. Há autores (Azevedo, 2004; Motta, 2009, p. 148), por sua vez, preocupados em destacar que essas tensões foram fundamentais dentro do processo de desmantelamento do regime servil brasileiro. Os conflitos que envolviam escravos transacionados de outras províncias acabaram por aumentar uma visão negativa da escravidão em diversos setores, principalmente entre fazendeiros que se relacionavam cotidianamente com esses cativos. O medo da “onda negra” - referência à associação feita entre a vinda de escravos de outras províncias e o suposto aumento da criminalidade, verificado nas décadas de 1860 e 1870 - era um dos principais argumentos daqueles que estavam convictos em defender o fim da escravidão. Sidney Chalhoub (1990, p. 27) também faz menção aos alarmes causados pelos cativos que migraram forçadamente para a região.

O tráfico interno deslocou para o sudeste, a partir de meados do século XIX, milhares de escravos que se viram subitamente arrancados de seus locais de origem, da companhia de seus familiares, e do desempenho das tarefas às quais estavam acostumados. Muitos destes negros reagiram agredindo seus novos senhores, atacando os donos das casas de comissões - lojas de compra e venda de escravos -, provocando brigas ou desordens que impedissem sua ida para as fazendas de café, fugindo e procurando retornar à sua província de origem.

Todas essas manifestações fizeram com que diversos setores, antes interessados na abolição 
gradual, passassem a encarar o fim da escravidão como algo a ser executado de maneira imediata. Para Chalhoub, é essencial, na análise das últimas décadas de escravidão, prestar atenção nas noções de cativeiro justo - ou minimante tolerável -, forjadas pelos próprios escravos. Ao se deparar com uma realidade que não conheciam, com tipos e ritmos de trabalho que lhe eram estranhos, os cativos advindos do Norte e Nordeste logo se viram em situações que não consideravam aceitáveis. Os transtornos por eles causados teriam provocado um estimável impacto político no processo de perda da legitimidade do escravismo.

[...] the Brazilian internal trade developed in a context of rising national and international mobilization against slavery. This [...] made the commerce in human beings a focus of 'political' struggle over the future of forced labor, involving masters, slaves, and other interested social groups; indeed, it could be argued that the crash of the slave market in 1881-83, reflecting a dramatic change in perception of 'chattel futures', was more of a historical watershed than the legal landmarks that announced partial emancipation in 1871 and 1885 (freedom, respectively, for children thenceforth born to slave mothers and sexagenarians) and complete abolition in 1888. (Slenes, 2004, p. 327)

Slenes (2004, p. 361) conceitua o mercado interprovincial de escravos que se forma a partir de 1850 como uma "arena política", em que as ações e expectativas dos escravos transacionados são fundamentais para se entenderem os conflitos que nela se desenrolam. O tráfico interprovincial, nesse sentido, foi decisivo para o processo abolicionista: as sociabilidades forjadas após essas migrações ocasionaram uma diminuição da legitimidade do escravismo. De um modo geral, podese dizer que essa migração forçada de escravos redimensionou a escravidão brasileira tanto no espaço como no tempo: além do deslocamento de cativos entre diferentes províncias, o comércio interprovincial de escravos representava um mosaico de expectativas quanto ao futuro do escravismo no país (Slenes, 2004, p. 327).

Essas divisões e conflitos tecidos após o tráfico interprovincial parecem ser bem factíveis. Os estudos que abordam essa problemática, no en- tanto, costumam focar sua atenção em regiões onde o escravismo não era, em meados do século XIX, um fenômeno recente. Geralmente, as análises se centram no Vale do Paraíba, a primeira região onde a cafeicultura prosperou em larga escala, ou então em municípios mais antigos do estado de São Paulo, como Campinas e Piracicaba, os quais se desenvolveram, inicialmente, a partir do cultivo de cana-de-açúcar. Todos esses lugares começaram a receber um volume significativo de escravos ainda em finais do século XVIII. Durante a primeira metade do século XIX, período em que se inicia o comércio interprovincial de cativos, as fazendas situadas nesses locais já apresentavam uma escravaria constituída. Ao receber escravos de outras regiões, surgiram as divisões e tensões expostas acima. Entretanto, o que podemos dizer das regiões nas quais a economia cafeeira prosperou somente a partir da metade do século XIX, ou seja, daqueles locais que começaram a receber uma expressiva quantidade de cativos apenas durante o período em que o comércio interprovincial adquire grandes proporções? Esse é o caso de São Carlos, município localizado no que se convencionou chamar de "novo" oeste paulista. ${ }^{6}$ Essa localidade se expandiu como região cafeeira somente em meados do século XIX. Diferentemente de outras cidades mais antigas, as lavouras dessa região não prosperaram antes dessa data. É a partir de 1850 que começaram a se instalar, em suas fazendas, um número expressivo de escravos, que viriam a constituir a principal fonte de mão de obra de sua cafeicultura. Desse modo, é correto afirmar que o contingente de escravos dessa localidade foi formado por cativos advindos de outras localidades, de outras províncias ou mesmo de regióes mais antigas do estado.

O que interessa sublimar é que não havia, nesse contexto, uma categoria de escravos que pudesse ser chamada de "estabelecidos". No de-

${ }^{6} \mathrm{O}$ "Oeste histórico” inclui o "Oeste velho” (o “quadrilátero de açúcar", centrado na região de Itu a Campinas), o qual se expande como área de grandes lavouras (produzindo açúcar e, posteriormente, café) a partir de 1790, e o "Oeste novo" (de Rio Claro para o norte-noroeste), que se consolida como área cafeeira principalmente após 1850 (Slenes, 1997, p. 456). 
correr do processo de migração, com certeza, surgiram outras formas de distinção entre os escravos. Contudo, pode-se dizer que, em São Carlos, não havia, anteriormente ao início do tráfico interprovincial, escravos já há muito tempo fixados, como foi o caso das regiões cafeeiras mais antigas. Nessas últimas, certas famílias de escravos se encontravam em determinadas propriedades desde gerações anteriores, mantendo uma relação muito próxima com seus senhores. Como foi dito anteriormente, esses cativos conheciam os códigos morais que estruturavam as relações entre senhores e escravos nesse contexto, aproveitando-se disso para estabelecer um círculo de relacionamento distinto com seus superiores. Tal situação trouxe sérias consequências para os cativos recém-chegados, os quais não recebiam o mesmo tratamento e eram considerados escravos inferiores, o que levou a maiores dificuldades no que se refere à afirmação de novos relacionamentos, tanto em relação a seus senhores quanto a outros escravos. A constituição de relações familiares, por exemplo, não era muito comum entre os cativos que migraram de outras regiões. Mas o que se pode dizer de regiões como a do "novo" oeste paulista, em que a questão dos “escravos estabelecidos” não apresenta muita força? Como foram processadas as redes de sociabilidade dos escravos recém-chegados nessa conjuntura?

Nesse artigo, argumenta-se que, no contexto das fazendas de café são-carlenses, alguns dos escravos advindos de outras regiões conseguiram firmar relações interpessoais duradouras, inclusive alianças de compadrio com seus senhores, ou então com outras pessoas de posses. Dentro da historiografia sobre as últimas décadas da escravidão, é fácil deparar com estudos que apontam para a formação de vínculos entre senhores e escravos. No que toca às fazendas cafeeiras de São Paulo, Slenes (1997, p. 271) afirma não ser incomum o fato de as relações de compadrio ultrapassarem, por vezes, os limites do cativeiro. ${ }^{7}$ Isso demons-

${ }^{7} \mathrm{Na}$ historiografia acerca do compadrio escravo, não são poucos os estudos que apontam para a existência de uma quantidade diminuta de casos em que o senhor foi o padrinho direto de um escravo. Essa tendência se ba- traria a necessidade de, num mundo hostil, os escravos criarem laços morais com pessoas de recursos, a fim de protegerem-se e a seus filhos. Segundo esse autor, os senhores de escravos do oeste paulista impunham o seu poder não somente pela força, mas também por meio da distribuição de "favores". Os proprietários instituíam, junto da ameaça e da coação, um sistema diferencial de incentivos. A proposta dessas ações, na percepção de Slenes (1997), era tornar os escravos cada vez mais dependentes por meio de obrigações morais. Melhores condições de trabalho, maiores chances de conseguir alforria e a atenuação dos castigos físicos eram "privilégios" dos escravos que mantinham boas relações com seus proprietários. A distribuição de prêmios por "mérito" entre os cativos fazia com que eles ficassem subordinados a seus próprios projetos domésticos, pois as chances de melhorar de vida estavam atreladas aos laços de lealdade com seus superiores. Tal situação, todavia, nem sempre acabava trazendo apenas benefícios. Se esses cativos gozavam dos favores dos fazendeiros, ao mesmo tempo não podiam dispensar a amizade de seus parceiros escravos, devido ao receio de sofrerem atitudes de revanchismo. Os relacionamentos com outros cativos, desse modo, não podiam ser dispensados nem mesmo por aqueles que desfrutavam dos benefícios advindos dos senhores. ${ }^{8}$ Os escravos do oeste paulista viviam, de acordo com Slenes (1997), em um mundo de força e de favor, no qual deviam tomar o máximo de cuidado na construção de suas redes de afinidades e de preferências. A escolha de parceiros e a execução de estratégias de vida nem sempre

seia na hipótese de que o papel de senhor, voltado para a disciplinarização do escravo, seria incompatível com o papel de padrinho, mais caracterizado por ser uma figura protetora. Tal premissa, todavia, considera essas características como mutuamente exclusivas, quando, na realidade, como ficará mais claro adiante, perpassam determinadas formas de controle nas relações de compadrio verticais. Proteger, em muitos casos, não deixa de significar controle ou disciplinarização. Para uma breve análise da historiografia sobre o compadrio escravo, consultar Bacellar (2011).

${ }^{8}$ As alianças com outros negros também poderiam ser de grande relevância para escravos e libertos. Como o objetivo deste artigo é refletir sobre as relações de poder que atravessavam os vínculos interpessoais, resolveu-se, todavia, priorizar a análise dos laços mantidos por negros (as) com fazendeiros, ou mesmo com pequenos proprietários. 
correspondiam, tomando as relações de sociabilidade desses sujeitos um caráter imprevisível.

\section{ENTRE O FAVOR E A (IN) GRATIDÃO: o assassinato de José Bueno do Prado}

As relações interpessoais tecidas no tempo de cativeiro teriam sido fundamentais até mesmo após a conquista da liberdade e da abolição definitiva. São comuns os relatos segundo os quais a consolidação de projetos familiares e de alianças com senhores e livres, assim como com outros escravos, teriam sido fundamentais nos mais variados contextos, para as trajetórias que ligavam a escravidão à liberdade. As relações pessoais constituídas ainda durante o período da escravidão teriam sido peças-chave na renegociação do estatuto social de ex-escravos durante o período posterior à abolição do regime servil. A inserção em novas relações de trabalho, a nova posição de cidadãos frente à esfera do Estado, a redefinição de determinadas formas de convívio, suas relações peculiares com o tempo e seus planos de mobilidade, ou seja, tudo que envolvia um projeto maior de liberdade ${ }^{9}$ passava pela intermediação da teia de vínculos estabelecida com outros agentes sociais.

Os laços firmados com pessoas de posse parecem ter perdurado mesmo entre os negros que permaneceram no oeste paulista após a abolição. ${ }^{10}$ É o que fica evidente na análise de alguns inquéritos policiais processados no município de São Carlos. No dia 29 de Março de 1901, por exemplo, João de Sampaio Pinto Leite, pardo, 40 anos, alfabeto, na-

${ }^{9}$ Ao longo de suas experiências, escravos e libertos construíram uma série de concepções de liberdade. A liberdade, desse modo, não pode ser encarada como um valor absoluto e totalmente dissociado da escravidão, mas sim um ideal construído a partir das diversas apropriações realizadas sobre a sua própria definição. Para uma discussão mais aprofundada sobre os significados da liberdade para os ex-escravos em diferentes contextos, ver Cooper, Holt e Scott, 2005.

${ }^{10} \mathrm{O}$ oeste paulista foi a região onde, a partir da década de 1880 , a política imigratória do governo paulista despejou cerca de dois milhốes de imigrantes (Andrews, 2007, p. 171). É de se acreditar que, com a competitividade de trabalhadores que usufruíam de uma melhor imagem frente à opinião pública, os recursos relacionais fossem até mais valorizados pelos negros depois de abolida a escravidão. tural de Campinas, acabou assassinando, com uma navalha, seu amigo José Bueno do Prado, 50 anos, casado, lavrador, natural de Brotas. Mariano Martins, concunhado de José Bueno, foi quem o socorreu, conduzindo João de Sampaio à polícia. No seu depoimento, consta o seguinte relato.

Que hontem depois do jantar, em casa do seu concunhado José Bueno do Prado, no bairro do Can-can deste município, elle conductor levantou-se da meza e dirigio-se para o serviço que pouco depois de lá chegar, ouvio gritos de socorro que reconheceu serem da mulher do seu concunhado e voltou incontinente para a casa de José Bueno, para ver o que ocorria, que ao chegar elle conductor vio José Bueno cahido por terra, ferido e com as tripas de fora, dizendo-lhe o offendido que fora João de Sampaio Pinto, vulgo João Machinista, quem o offendera; que nesse momento elle conductor vio que João de Sampaio Pinto, ainda armado de navalha tentava fugir e então reunio-se com Julio de Lamano e Joaquim Antonio da Silva, sahindo ao encalço de João Machinista, o agressor, e conseguindo prendel-o, sendo para isso preciso deu-lhe umas cacetadas [...]. (Fundação Pró-Memória de São Carlos (FPM), caixa $\left.199, \mathrm{n}^{\mathrm{O}} 118,1901\right)$.

José Bueno veio a falecer em decorrência dos ferimentos sofridos durante o confronto com João Sampaio. Antes disso, ele conseguiu prestar depoimento e discorrer um pouco acerca da relação que tinha com seu agressor. Segundo José Bueno, o réu "morava de favor" em seu sítio, juntamente com os dois filhos, de nome Sebastião e Henrique. O último, inclusive, "João Pinto entregara aos cuidados delle depoente". João Sampaio estava morando provisoriamente em sua propriedade, pois estava esperando a época da colheita para se empregar como maquinista em alguma fazenda. ${ }^{11}$ José Bueno ressaltou ainda que, mais ou menos há quinze dias, precisou interromper uma briga do acusado com Sebastião, pois o primeiro tentava matar o seu filho. Decidiu, desse modo, separar os dois de quarto, passando João Sampaio a dormir na sala. José Bueno afirmou ter, no dia em que foi atacado pelo último, intermediado um novo atrito entre o pai e o mesmo filho, porém dessa vez ex-

${ }^{11}$ Maquinista era aquele que trabalhava com a máquina de beneficiamento dos grãos de café. 
pulsou João Sampaio de sua casa. A partir dessa sua determinação, o réu teria usado uma navalha para cortá-lo. A vítima finalizou seu depoimento mencionando não nutrir de nenhum tipo de inimizade com seu ofensor; ao contrário, sempre procurava protegê-lo.

O filho com quem João Sampaio discutia, Sebastião Pinto de Sampaio, 20 anos, operário, solteiro, natural de São Carlos, disse, em seus esclarecimentos perante o Juiz, que seu pai falava alto no meio da discussão, porque "elle depoente é meio surdo”. José Bueno, assustado com os gritos proferidos por seu pai, veio perguntar o que estava acontecendo. João Sampaio, por seu turno, teria respondido "não é nada, é negócio de família”. José Bueno, então, puxara seu pai pelas orelhas e o arrancara do quarto, momento em que ele sacou uma navalha e cortou-o. Por fim, Sebastião revela nunca ter presenciado nenhuma espécie de discussão entre seu pai e José Bueno. João Sampaio foi, no entanto, condenado a dez anos e seis meses de prisão. Seu advogado ainda tentou recorrer da decisão, mas o Tribunal manteve a pena.

A frase proferida por João Sampaio, no instante em que José Bueno procurava estar a par da situação - "é negócio de família" -, demonstra um discernimento do maquinista acerca dos seus laços afetivos: as relações familiares não se confundiam com os outros vínculos, mesmo que esses lhe fornecessem alguma espécie de auxílio e chegassem até o estado de coabitação. Embora morasse "de favor" na casa de José Bueno, bem como tivesse entregado seu filho mais novo "aos cuidados" do próprio, ele não o considerava parte de sua família e, por isso, não aceitava as interferências em sua autoridade de pai. Estudando as relações familiares das classes populares cariocas durante o período pós-abolição, camada na qual estavam inseridos muitos libertos e seus descendentes diretos, Chalhoub (2001, p. 175-176) encontrou dificuldades em estabelecer os significados que esse grupo atribuía ao termo "família”. De acordo com suas conclusões, esses indivíduos se envolviam em redes de solidariedade e de ajuda mútua muito extensas, o que tornou problemático o estabelecimento dos limites entre as redes de solidariedade ditas "familiares" e as de outro tipo, como as relações de compadrio, por exemplo. Cabe sublinhar aqui o fato de a noção conjugal ou individualista de família ser uma invenção da modernidade. Anteriormente ao que se convencionou chamar de "época moderna", período correspondente, na Europa, ao pós-século XVIII, as sociabilidades familiares mal se distinguiam dos laços de vizinhança, comunitários e "públicos". A sociabilidade conjugal e individualista remete à ideia burguesa de família, a qual se vincula, por sua vez, à produção dos sentimentos de intimidade ou privacidade (Ariés, 1981). Essa noção de família como conjunto de vínculos distinto dos outros laços afetivos acabou por se expandir para diversos lugares do mundo, ganhando variados contornos em diferentes conjunturas. É essa percepção de família, por exemplo, que as políticas públicas das principais cidades brasileiras, através da propagação de agentes sanitários e de forças jurídico-policiais, esforçavam-se em impor para as camadas populares durante o início do século XX.

É de fundamental importância atingir como alvo privilegiado e seguro esta construção imaginária da sociedade moderna: a família nuclear. A casa deve constituir um novo espaço normalizado de relações estáveis, naturalizadas e assépticas, onde podem se aprofundar os sentimentos familiares e estreitarem-se os vínculos entre os membros da família [...]. As investidoras sanitárias apontam a higiene das habitações populares como o meio mais eficaz para erradicar a raiz do problema (infecções e moléstias contagiosas) e recuperar a saúde dos desfavorecidos. Desaglomerar os pobres, arejar e iluminar os compartimentos e eliminar miasmas e germes, observando a mais rigorosa higiene constituem tecnologias disciplinares do poder médico. Tática de antiaglomeração: primeiro passo para a formação do sentimento de intimidade e da sedução pela propriedade privada (Rago, 1985, p .42).

Alguns estudos (Caulfield, 2000; Esteves, 1989) ressaltam o caráter moralizador presente nos projetos republicanos, chamando a atenção, contudo, para os limites em se impor uma moralidade familiar única. De acordo com eles, principalmen- 
te quando se observa o comportamento das chamadas "classes populares", é difícil perceber um modelo único de relações familiares. Isso não é o mesmo que dizer, todavia, que essas relações pareciam indiscerníveis. Pelo menos no que diz respeito ao caso acima descrito, era operacionalizada uma hierarquização entre os papéis sociais inscritos nas relações pessoais: o papel de pai, de João Sampaio, não poderia, na percepção do próprio, sofrer a interferência de um amigo ou compadre. A gramática social inscrita nesses papéis, cabe lembrar, possui um caráter dinâmico, sendo seus conteúdos constantemente renegociados segundo as interações que se estabelecem. O que se procura demonstrar aqui, no entanto, é que, na visão de João Sampaio, havia uma nítida distinção entre os vínculos e as reciprocidades encerrados na lógica familiar, por um lado, e aqueles referentes a outros tipos de relações interpessoais, por outro.

Não era raro, durante a virada do século XIX para o século XX, encontrar famílias de exescravos morando, no mesmo espaço doméstico, com outras famílias, em fazendas ou em propriedades rurais menores. João Sampaio, como foi mencionado acima, nasceu em Campinas, vindo para São Carlos muito provavelmente, como um escravo. ${ }^{12}$ Conseguiu constituir família nessa região, uma vez que seu filho de 20 anos é natural desse município, bem como criar laços sociais que se mostraram fundamentais para sua trajetória como homem livre.É o caso de sua estadia na casa do proprietário de um sítio, para o qual, inclusive, entregou os cuidados de seu filho mais novo. Olhando para o caso, pode-se sugerir que, nos cálculos dele, parecia interessante para o filho ficar mais próximo de um pequeno proprietário rural do que dele próprio, um maquinista que

${ }^{12}$ Embora a historiografia relegue mais atenção ao comércio interprovincial, não era incomum o comércio de escravos entre cidades paulistas. No que se refere especificamente a São Carlos, pode-se dizer que diversos dos fazendeiros que estabeleceram propriedades nas suas áreas eram procedentes, ou então possuíam parentes, em regiões cafeeiras mais antigas do estado, como Campinas e Piracicaba. Isso pode ter facilitado o comércio de escravos entre esses municípios. Sobre um estudo que aborda o comércio intraprovincial de escravos, ver Motta (2006). perambulava de fazenda em fazenda atrás de emprego. A ligação pessoal de João Sampaio com José Bueno foi, portanto, fundamental para o primeiro. Ele, um trabalhador temporário da economia cafeeira, ${ }^{13}$ conseguiu, por meio de sua amizade com o proprietário de um sítio, além de um abrigo para a família em um momento em que se encontrava desempregado, estender esses laços para o benefício do filho mais novo. Em São Carlos, João Sampaio constituiu família e presenciou os últimos anos do escravismo. Consequentemente, ele pôde perceber as fragilidades dos ex-escravos frente às relações de força que compunham o período pós-emancipação. Os vínculos que conseguiu cultivar com um pequeno proprietário foram, dessa maneira, fundamentais para as suas relações familiares: através deles é que ele poderia propiciar a seus filhos uma condição melhor do que a sua.

O que João Sampaio talvez não tivesse previsto, todavia, é que os benefícios obtidos por meio desses vínculos poderiam, às vezes, ter um preço muito alto. Em seu depoimento, José Bueno relatou, indiretamente, a hierarquia que predominava na sua relação com João Sampaio. Ao dizer "que sempre procurava proteger o réu" e que morava de "favor" na sua casa, ele deixa implícita uma suposta gratidão que deveria nutrir por João Sampaio. A reciprocidade inscrita no binômio favor e gratidão demonstra, desse modo, o complexo jogo de poder que mediava esse tipo de relacionamento, em que qualquer leitura equivocada das regras de convivência estabelecidas poderia terminar em conflito. Analisando o desenvolvimento do conceito de capital social - entendido como a capacidade de os indivíduos garantirem benefícios advindos da sua localização em redes sociais -, Portes (1998, p. 15) destaca o fato de essa noção sugerir não somente as consequências positivas da sociabilidade, mas também o caráter normativo e excludente presente nos recursos relacionais. Isso

${ }^{13}$ Grande parcela dos negros que permaneceram trabalhando nas fazendas de café após a chegada massiva de imigrantes passou, como no caso de João Sampaio, a ocupar empregos subsidiários, sendo chamados a trabalhar somente em determinados períodos do ano agrícola. Para maiores informações sobre essa situação, ver (Holloway, 1984; Vangelista, 1991). 
porque os vínculos sociais, ao criarem certos laços de sociabilidade entre um grupo de pessoas, permitem a circulação de formas de controle social e, além disso, pressupõem a exclusão de outros indivíduos. O alcance das potenciais garantias e obrigações implícitas nas relações interpessoais depende, por seu turno, da quantidade, do conteúdo e da intensidade dos laços que ligam o conjunto delimitado de indivíduos (Portes, 1995, p. 9). No caso das análises acerca das alianças de compadrio estabelecidas por escravos e libertos, são poucos os estudos que procuram enfatizar os potenciais custos implícitos nas relações de poder sob as quais se firmavam os vínculos com homens livres, senhores e demais pessoas com posses.

A ligação estreita entre João Sampaio e José Bueno pode representar, diante de um determinado ponto de vista, uma linha tênue demais, que atravessava as relações familiares e as relações de amizade e compadrio. Contudo, o primeiro possuía um discernimento bem claro de suas relações de parentesco e de sua identificação como pai. Seus vínculos pessoais com uma pessoa de certa posse não significavam a continuidade de determinadas relações familiares. Sua relação com José Bueno possibilitou um auxílio a toda sua família, mas, por outro lado, também significou o enfraquecimento de uma moralidade que o instituía como pai, haja vista o fato de o proprietário do sítio se sentir no direito de mediar a relação de João Sampaio com os seus filhos. Esse último, provavelmente, interpretou a interferência de José Bueno na discussão que tinha com seu filho como uma intromissão que poderia minar sua autoridade de pai.

\section{AS CONTENDAS NAS RELAÇÕES DE COMPADRIO: o conflito envolvendo Lusia, Ozoria e a família Camargo}

O fato de alguns ex-escravos entregarem os cuidados de seus filhos a pessoas próximas não significava o abandono da gramática moral relacionada a certos papéis familiares. É o que deixa implícito o exame de outro inquérito (São Carlos,
1893), cujos réus são Gabriel Dionisio da Silva, preto, 30 anos, carroceiro, solteiro, natural da Bahia, e "Cancio", espanhol, administrador. Na noite do dia 25 de Março de 1893, o primeiro recebeu o convite de Lusia Ignacia do Espírito Santo, preta, 32 anos, solteira, natural da Bahia, para ir até uma fazenda vizinha, juntamente com mais dois homens, buscarem a filha da referida mulher. Chegando ao local, próximo à sede da fazenda, Lusia disse para esperarem ali enquanto ela encontrava sua filha. Passado alguns instantes, todavia, Lusia voltou correndo aos gritos e pedindo para fugirem. O grupo então se dispersou no meio do cafezal. Gabriel, que encontrou refúgio embaixo de uma árvore, foi avistado por Cancio, o administrador da fazenda onde estavam. Indagado sobre o que fazia naquele local, ele teria dito que "estava passeando". Cancio o advertiu afirmando não ser o horário e nem o lugar para passear, ordenando-lhe ir embora antes que "levasse fogo". Diante de tal situação, Gabriel retrucou dizendo "fogo por fogo aqui também tem". Logo em seguida, armou uma espingarda que carregava consigo e disparou. Sua arma, porém, falhou, dando a oportunidade para Cancio desfechar-lhe dois tiros. Gabriel foi depois socorrido por seus companheiros e levado para o hospital da cidade, onde recebeu a notícia de que tinha ficado cego de um de seus olhos. No julgamento, Cancio e Gabriel foram absolvidos.

Devemos nos concentrar aqui no motivo que levou Gabriel a se dirigir a tal fazenda no meio da noite, ou seja, a investida de Lusia para trazer sua filha. Segundo o depoimento do proprietário da fazenda, Rocha Camargo Arruda, 50 anos, lavrador, casado, natural de Campinas, Lusia tinha "dado" a filha à mulher dele há cerca de um ano, com o anseio de a menina aprender serviços domésticos. Por volta de oito dias atrás, entretanto, a mãe da jovem tentou levá-la de volta, sem avisar ao fazendeiro. A filha de Lusia, por seu turno, não aceitou ir sem o consentimento da "madrinha". Rocha revela ter conversado com Lusia na ocasião. Ela lhe teria manifestado o desejo de trazer a filha de volta, pois já havia arranjado casamento para a menina. Ele, por sua vez, adiantou que, se fosse 
esse o caso, bastaria Lusia trazer todos os papéis referentes ao matrimônio. Sendo assim, Rocha até ajudaria no casamento. $\mathrm{O}$ fazendeiro diz ter comunicado a um Juiz sobre a situação, sendo autorizado por ele a permanecer com a jovem em casa. Lusia, quando interrogada, admitiu a versão de Rocha. O motivo de sua pretensão de tirar a filha da guarda da família do fazendeiro seria o boato de alguns de seus amigos, que lhe disseram "que a menina podia lá se perder". Ela afirma ter ido também à procura da Justiça e manifestado seu desejo de tirar a filha daquela fazenda. O Juiz teria revelado a ela a necessidade de se arranjar o noivo e dar entrada nos papéis para, posteriormente, ele poder mandar buscar a jovem. Algumas pessoas, porém, contaram a Lusia que sua filha, mesmo tendo 15 anos, não tinha o direito de se casar. De "cabeça quente", ela resolveu, então, "furtar" a própria filha. Chegando à fazenda onde se encontrava a filha, Lusia foi surpreendida pelo administrador e saiu correndo assustada, o que culminou no conflito citado. O pivô de todo o ocorrido, Ozoria Maria da Conceição, 15 anos, “serviços domésticos”, natural da Bahia, relatou estar satisfeita na casa de Rocha, não pretendendo deixar sua "madrinha" para voltar a morar com sua mãe, visto "que o que sabe deve tudo a senhora deste [a mulher de Rocha]".

Um dos aspectos relacionados à prática de deixar os cuidados de filhos a compadres era o de que, como foi sugerido na análise do inquérito anterior, diversos negros tinham como ideia fazer seus filhos aprenderem um trabalho capaz de propiciarlhes melhores oportunidades. No caso específico desse último inquérito, percebe-se o interesse de Lusia de que a filha aprendesse um tipo de trabalho diferente do seu, pois a menina realizava apenas serviços domésticos na casa do fazendeiro, ou, pelo menos, que ela pudesse se aproveitar das afinidades com uma família de fazendeiros. Tal vínculo de intimidade, todavia, deixou Ozoria suscetível a certas relações de dependência para com a família em questão. Luisa, tão logo soube que a filha poderia "se perder"14 na casa do fazendeiro, tratou de

${ }^{14}$ Essa afirmação sugere que Ozoria poderia sofrer o assédio de pessoas ligadas à família de Rocha. No inquérito operacionalizar o que ela entendia ser seu papel, isto é, o papel de mãe. Buscando resguardar a "honra" da filha, ela empenhou-se em tentar controlar sua sexualidade, arranjou-lhe casamento e fez de tudo para a filha sair da proteção do fazendeiro.

As disputas travadas por Luisa e Rocha Camargo em torno da guarda de Ozoria podem revelar indícios acerca dos conflitos entre negros e fazendeiros durante o pós-abolição. Terminado o escravismo, muitos fazendeiros e ex-escravos tentaram utilizar-se das mesmas estratégias que adotavam nos tempos de escravidão, mas tentando estabelecer novas formas de distinção social (Albuquerque, 2009, p.113; Fraga Filho, 2006). A abolição, mesmo não sendo uma ruptura radical, não representou somente o fim de uma relação de propriedade, mas também a perda das referências fundamentais na constituição da identificação de escravos e senhores de terra. "A certeza de que o mundo social não podia mais ser definido pela oposição entre senhores e escravos comprometia vínculos pessoais e referências de autoridade - não só relações de trabalho. Não eram apenas os trabalhadores que os proprietários perdiam, mas a sua própria posição hierárquica estava em jogo" (Albuquerque, 2009, p. 125). Havia todo um "lugar social" construído desde o período colonial em torno dessas duas categorias. Muitos ex-senhores, ao fim da escravidão, viram-se fora desse lugar que estruturava toda a lógica da arquitetura social. Com o fim definitivo do escravismo, portanto, foram suspensas diversas regras que balizavam as disputas de poder entre senhores brancos e negros subalternos.

Ao que tudo indica, pela data em que ocorre o inquérito e pela sua província de procedência, Lusia foi realmente uma ex-escrava. Mais precisamente, uma escrava que veio parar em São Carlos a partir do comércio interprovincial de cati-

descrito, Ozoria aparece como natural da Bahia, o que torna difícil a hipótese de que ela seja filha de Rocha. Durante as últimas décadas da escravidão, era relativamente comum, no oeste paulista, os senhores terem filhos (as) com suas escravas e eles serem cuidados pelas mulheres desses fazendeiros como filhos legítimos ou como afilhados. Para mais detalhes sobre esses casos, consultar Slenes (1997). 
vos que perdurou após 1850. O que é mais emblemático, entretanto, é o fato de ela ter conseguido trazer consigo uma filha. As pesquisas sobre o comércio interprovincial de escravos são unânimes em afirmar que a grande maioria dos escravos transacionados para o Sudeste possuía como perfil o fato de serem homens e jovens, ou seja, eram comercializados para a economia cafeeira, principalmente aqueles escravos que estavam em idade para o trabalho. De acordo com boa parcela dos estudos sobre esse tema, muitas mulheres acabavam ficando para trás no tráfico interno, o que ocasionava as tão ressaltadas separações familiares. ${ }^{15} \mathrm{O}$ que parece justificar a não separação de Ozoria e Lusia é o fato de a primeira nunca ter sido uma escrava, uma vez que nasceu após 1871, data em que se promulga a Lei do Ventre Livre. ${ }^{16}$ Essa lei proibia a separação de ingênuos cuja mãe escrava tivesse sido envolvida em alguma venda. Nesse caso específico, o cumprimento de tal obrigação parece explicar o fato de Lusia ter, muito provavelmente, migrado para o Sudeste junto com Ozoria.

Lusia se instalou com a filha em uma fazenda de São Carlos (não sabemos, no entanto, se veio da Bahia direto para essa localidade) e conseguiu, além disso, firmar relações de compadrio com uma família de fazendeiros. Após isso, Lusia possivelmente resolveu, já como liberta, sair da propriedade onde foi escrava, deixando a filha sob os cuidados dos padrinhos. A permanência de Ozoria na casa desses últimos, como foi visto, não se estabeleceu como Lusia esperava. Ao tentar salvar a filha de boatos, ela viu sua autoridade de mãe ser con-

${ }^{15}$ Há menções de que algumas escravas que foram separadas de seus familiares acabaram sendo comercializadas para grandes centros urbanos, sobretudo para a cidade do Rio de Janeiro, onde se tornavam domésticas ou prostitutas. Da mesma maneira, há relatos de escravas que tentam a todo custo restabelecer seus vínculos, como no caso de mães que fogem do Nordeste e vão até o Rio de Janeiro atrás das filhas que foram delas arrancadas através de uma operação de venda. Mais casos como esses são relatados em Graham, (2002).

${ }^{16}$ A Lei do Ventre Livre, também conhecida como "Lei Rio Branca”, estabelecia, dentre outras determinações, que os filhos de escravos nascidos a partir daquela data seriam considerados livres. Filhos de mães escravas, os ingênuos beneficiados por essa lei eram obrigados a ficar sob a tutela dos senhores de suas mães ou do governo até completarem a maioridade (21 anos). Na prática, muitos escravocratas mantiveram os ingênuos nas suas propriedades, tratando-os como se fossem escravos. testada, tanto pela recusa do fazendeiro em entregála quanto pela rejeição da própria em seguir com a mãe. Para quem tem conhecimento das separações causadas pelo tráfico interprovincial, o que é muito plausível, no caso de Lusia, tal fato não é de pouca relevância. Como foi relatado anteriormente, ter os laços familiares rompidos segundo a vontade de senhores foi, para muitos dos escravos que migraram forçadamente para o Sudeste, uma das piores experiências do escravismo.

[...] sem dúvida, um dos aspectos mais traumáticos da escravidão era a constante compra e venda de seres humanos [...] Os negros tinham suas próprias convicções sobre o que era o cativeiro justo, ou pelo menos tolerável: suas relações afetivas mereciam algum tipo de consideração; os castigos físicos precisavam ser moderados e aplicados por motivo justo; havia maneiras mais ou menos estabelecidas de os cativos manifestarem sua opinião no momento decisivo da venda. O tráfico interno deslocou para o sudeste, a partir de meados do século XX, milhares de escravos que se viram subitamente arrancados de seus locais de origem, da companhia de seus familiares, e do desempenho das tarefas às quais estavam acostumados (Chalhoub, 1999, p. 27).

Segundo Castro e Rios (2005, p.184), o direito de não se separar da família consistiu um dos principais pontos de luta de muitos cativos; era um dos aspectos mais comuns dentro dos ideais de liberdade forjados por distintas experiências escravas. ${ }^{17}$ Conforme foi ressaltado na introdução, a historiografia sobre as últimas décadas da escravidão está repleta de casos em que a busca pela manutenção das relações familiares, por parte de cativos que foram transferidos para as fazendas cafeeiras do Sudeste por meio de operações de venda, terminou em situações de violência ou até mesmo em verdadeiras tragédias. Lusia conseguiu permanecer junto com a filha (pelo menos com essa, especificamente) durante a vinda para o Sudeste, porém, cinco anos apenas após a abolição, ela se via, contra sua vontade, separada dela; agora não mais diretamente devido, à institucionalização do

${ }_{17}$ Em 1869, foi promulgada uma lei que proibia a venda separada de membros de uma mesma família de escravos. Muitos senhores, todavia, ainda continuaram se utilizando de tal prática após essa data. 
escravismo, mas por causa das próprias relações interpessoais que ela mesma acreditava serem benéficas para a filha.

A estratégia traçada por Lusia, ao deixar a filha sob os cuidados de um fazendeiro, acabou minando sua posição hierárquica dentro da própria lógica familiar que definia essa mesma estratégia. A identificação como mãe, embora continuasse a fazer parte de um dado repertório discursivo, ficava distorcida quando, como no caso descrito, é a relação entre os padrinhos e afilhados que passa a fornecer o parâmetro na constituição do binômio filha(o) subalterna(o) e pais superiores. Ozoria deixa claro, em seu depoimento, que a saída da casa dependia, no que diz respeito a ela, da vontade dos padrinhos, e não do desejo de sua mãe. Dito em outras palavras, a referência de autoridade, no campo privado, passara a se concentrar nas relações de compadrio. A saga de Lusia na tentativa de trazer a filha de volta explicita a busca dessa negra pela retomada desse referencial hierárquico. Sua entrada em uma fazenda onde ela sequer trabalhava, sem qualquer tipo de permissão, é um indício de que a ex-escrava queria, a qualquer custo, retirar a filha do controle do fazendeiro. Ainda que de forma implícita, esse conflito evidencia que as tensões pós-abolição continuavam dialogando com a experiência do escravismo, embora agora com novos significados. O fazendeiro Rocha Camargo se achava no direito de poder exercer uma autoridade sobre a filha de uma antiga escrava, mesmo contra a vontade da própria mãe. Por outro lado, as investidas de Lusia demonstram que a liberta não mais considerava legítima as relações da filha com os padrinhos e via, como seu dever, a desconstrução desses laços que ela mesma outrora estabelecera. Esse seu comportamento tinha impacto direto nas lutas em torno da negociação do seu novo estatuto social: ${ }^{18}$ o controle dos fazendeiros sobre sua filha a remetia, muito provavelmente, a lembranças do tempo de cativeiro. Não

${ }^{18}$ Os estatutos sociais de cada sujeito não são fixos nem únicos. Não se considera, todavia, que a ideia de "contingência” possa ser mecanicamente aplicada na análise da (re) construção das hierarquias de uma sociedade pós-escravista. sabemos se Lusia, no decorrer de sua vida como escrava, sofreu diretamente alguma espécie de separação familiar forçada. Todavia os afastamentos ocasionados pelo comércio interprovincial tornaram-se, sem dúvida, muito marcantes para todos os escravos que vivenciaram as últimas décadas da escravidão nas lavouras do Sudeste, mesmo para aqueles que não foram diretamente afetados por eles. As imagens e informações acerca desses episódios circulavam assiduamente, sem contar o fato de a ameaça de separação por venda ter sido uma constante para todos os cativos que mantinham vínculos afetivos. Conforme observaram Castro e Rios (2005, p.50), “[...] são os direitos de ir e vir, de dispor de seu próprio corpo e de regular autonomamente as relações de família que marcam as descontinuidades a serem ressaltadas entre 0 'Tempo do Cativeiro' e o ‘Tempo da liberdade”.

O fundamental [...] é enfatizar que, para os negros, a liberdade significava, entre outras coisas, o fim de uma vida constantemente sujeita às vicissitudes das transações de compra e venda. As feridas dos açoites provavelmente cicatrizavam com o tempo; as separações afetivas, ou a constante ameaça de separação, eram as chagas eternamente abertas do cativeiro (Chalhoub, 1999, p. 243-244).

Lusia se sentia no dever, agora como uma livre, de não deixar que os laços sociais com um ex-senhor se sobrepusessem a seu papel de mãe. Sendo assim, pode-se afirmar que as relações familiares eram também de relevância dentro das disputas cotidianas relacionadas aos significados políticos construídos em torno da condição de liberto ou livre. ${ }^{19}$ A constituição de um ideal de liberdade passava, além da questão mais diretamente relacionada ao trabalho e à mobilidade, pelo estabelecimento de determinadas lógicas familiares, muitas delas dificultadas, ou então até mesmo impedidas, durante a escravidão. ${ }^{20}$

${ }^{19}$ Castro (1997, p. 383) chama a atenção para o fato de, finda a escravidão, muitos ex-escravos, na busca por se afastarem cada vez mais das associações com o cativeiro, estarem empenhados em se afirmar como cidadãos livres, e não como libertos.

${ }^{20}$ Estudando os crimes passionais cometidos por escravos campineiros, Cristiany Rocha (2004) chegou à conclusão de que os cativos envolvidos no comércio interprovincial 
Antes de tentar invadir a fazenda para trazer Ozoria de volta, Lusia foi procurar um Juiz, com a intenção de que a Justiça interviesse a seu favor. A procura pela Justiça ou pela polícia, relata Chalhoub (1999, p. 176), já não era insignificante entre os escravos durante as últimas décadas de escravismo, pois muitos recorriam a essas instituições com a intenção de protestar contra maus-tratos sofridos, ou mesmo contra acordos de alforria não cumpridos. É de se acreditar que, após 1888, a confiança no Estado tenha até aumentado entre a população negra de um modo geral. Contudo, essa confiança deve ser bem relativizada. Muito possivelmente, o recurso de consulta a um Juiz representou a busca de recuperação da guarda da filha, umas das últimas medidas a serem tomadas por Lusia. Recurso, aliás, ineficiente, haja vista que o Juiz praticamente nada fez para tirar Ozoria da casa do fazendeiro. No embate entre uma ex-escrava e uma família de grandes proprietários locais, é de se acreditar que, no âmbito da Justiça, as chances de uma ação favorável para a primeira eram concretizadas apenas em casos extremos. Oideal de cidadania cristalizado nas recém-criadas instituições republicanas estava imerso em processos de racialização, ${ }^{21}$ o que delimitava um caráter repressivo, em relação aos negros e negras, por parte das ações do Estado. Orientadas pela experiência adquirida no tempo de cativeiro, as alianças interpessoais com pessoas de posse permaneceram, portanto, como uma das principais fontes de sustentação social para alguns libertos. Os jogos de poder envoltos nessas relações, entretanto, podiam, como foi visto, desestabilizar outras lógicas presentes no ideal de liberdade traçado por diversos negros.

eram os mais sensíveis a qualquer ameaça em relação ao rompimento de seus laços afetivos, o que acabava levando, às vezes, a reações violentas de ciúme. Esse tipo de comportamento pode ser explicado, em parte, pelas experiências de separação trazidas pelas operações de venda e, também, pelas dificuldades de estabelecerem novos vínculos em algumas fazendas do Sudeste.

${ }^{21}$ Ancorado nos preceitos biologizantes da noção de progresso gestada em fins do século XIX, o Estado republicano foi palco de uma série de políticas com viés racista. Um dos principais exemplos dessas políticas foi o projeto de subsídio à vinda de imigrantes, sendo seu intuito a promoção de um "embranquecimento" do país (Schwarcz, 1995; Ortiz, 1982; Hofbauer, 2003).

\section{CONSIDERAÇÕES FINAIS}

Justamente por estarem transcritos em inquéritos policiais, é difícil inferir algum tipo de generalização sobre esses dois casos. Partindo apenas desse material, é complicado, por exemplo, conhecer a assiduidade com que ex-escravos advindos de outras regiões conseguiram estabelecer laços familiares e sólidas relações interpessoais com fazendeiros em São Carlos. O exame desses inquéritos, porém, possibilitou a análise de alguns dos conteúdos sociais presentes nessas relações, bem como da forma como as experiências criadas a partir da migração para esse contexto foram fundamentais dentro dos conflitos que caracterizaram o período pós-emancipação. Primeiramente, percebeu-se que, tratando especificamente do caso de são Carlos, região onde as fazendas cafeeiras tiveram de importar quase todos os seus escravos a partir da metade do século XIX, foi possível a alguns ex-escravos o estabelecimento de vínculos com pessoas de certa posse que perduraram após a abolição. Os cativos que foram transacionados para essa localidade não tiveram a concorrência de escravos já fixados há um longo tempo nas fazendas para onde foram enviados. Os vínculos que conseguiram constituir, por sua vez, possibilitaram auxílios que variavam desde a disponibilidade de habitação até o cuidado dos próprios filhos. Essa última prática, aliás, pareceu ser uma estratégia familiar bem consolidada, cujo objetivo principal seria o de permitir melhores perspectivas de vida para eles. ${ }^{22}$ Ela, entretanto, não deixava de estar suscetível a certos desacordos: ao operacionalizarem certas hierarquias, padrinhos poderiam entrar em choque com outros referenciais de autoridade presentes nas relações familiares que informavam essas mesmas estratégias. A constituição dos papéis de pai e de mãe, situada no centro da própria estratégia familiar, era colocada em xeque pela gramática de po${ }^{22}$ Nesse caso, as redes sociais não devem ser pensadas
somente a partir de uma perspectiva que as encare como
a "instrumentalização da subjetividade”, pois elas pres-
supõem uma abordagem relacional, isto é, o capital soci-
al referente ao posicionamento em determinada rede
depende não somente do próprio agente, mas das ações
e do reconhecimento dos outros membros. 
der na qual as relações de compadrio estavam inseridas. Na leitura dos inquéritos, tornou-se visível que aqueles que prestavam alguma espécie de "favor" para uma família de negros tentavam, de acordo com a circunstância, manter uma relação de interferência direta nos conflitos surgidos entre pais e filhos. O pai e a mãe relatados nesses inquéritos, por sua vez, não aceitaram passivamente as interferências nos seus respectivos papéis familiares. Eles estavam informados, muito provavelmente, pelas experiências de separações familiares causados pelo comércio de cativos após 1850. Para eles, suas relações familiares estavam bem definidas e não poderiam se confundir, de forma alguma, com os laços de compadrio ou de amizade.

De um modo geral, pode-se afirmar que havia códigos morais que, ao definirem determinadas normas de sociabilidade, balizavam as relações interpessoais entre negros e seus compadres ou amigos. A afirmação desses códigos, por seu turno, passava também pela busca de um distanciamento cada vez maior das associações com um estatuto social semelhante ao de cativo. A liberdade de poder mediar a trajetória dos filhos, mesmo se isso significasse o afastamento em relação a eles, era um aspecto do maior interesse dos negros que ainda conviviam com as lembranças do que era ser escravo e, sobretudo, com as recordações e traumas trazidos pelos comércio de escravos. Entregar os "cuidados" de um filho ou uma filha seria uma decisão que deveria partir dos próprios pais e, como foi observado, uma decisão que poderia ser mudada a qualquer momento, dependendo do decorrer das interações entre filhos e padrinhos. As relações interpessoais tecidas por alguns negros durante o período pós-abolição estavam, nesse sentido, constantemente sob tensão. Se, por um lado, elas constituíam uma das principais (dentre as poucas) bases de obtenção de recursos materiais e simbólicos para esse grupo, também faziam parte de um processo de renegociação de certas identificações e hierarquias.

Os filhos também ficavam em uma situação complicada ao verem seus pais e padrinhos duelando pela autoridade sobre eles. Chamados para depor, eles tiveram de se posicionar frente a esses conflitos e escolher um lado para apoiar. Esse apoio, por seu turno, dependia da situação em que esses jovens se encontravam e também da intensidade dos vínculos que mantinham com seus pais e com seus padrinhos. Por estar com 20 anos, trabalhando e na iminência de ver o pai na cadeia, Sebastião Sampaio preferiu defendê-lo nos depoimentos que prestou junto à polícia e ao Juiz. Porém Ozoria Conceição, com 15 anos, parecia vislumbrar uma condição melhor na casa de seus padrinhos fazendeiros do que se estivesse com sua mãe, assim como aparentava estar um pouco distante em relação a essa última, optando por não apoiar as decisões de Lusia. Para esses jovens, que já nasceram livres, as separações familiares ocasionadas pelo comércio de escravos pareciam não causar tanta aflição. Os processos de inferiorização a que eles estavam sujeitos já eram distintos daqueles vivenciados por seus pais.

Recebido para publicação em 4 de fevereiro de 2012 Aceito em 19 de março de 2013

\section{FONTES PRIMÁRIAS}

Inquéritos Policiais. Fundação Pró-Memória, São Carlos.

\section{REFERÊNCIAS}

ALBUQUERQUE, Wlamyra. O jogo da dissimulação. Abolição e cidadania negra no Brasil. São Paulo: Companhia das Letras, 2009.

ALENCASTRO, Luiz Felipe de. O trato dos viventes: a formação do Brasil no Atlântico Sul. São Paulo: Companhia das Letras, 2000.

ANDREWS, George R. Negros e brancos em São Paulo. Bauru-SP: Edusc, 1998.

América afro-latina, 1800-2000. São Carlos,SP: Edufscar, 2007.

ARIÈS, Philippe. História social da criança e da família. Rio de Janeiro: Guanabara Koogan, 1981.

AZEVEDO, Célia Maria Marinho. Onda negra, medo branco: o negro no imaginário das elites, século XIX. São Paulo: Annablume, 2004.

BACELLAR, Carlos de Almeida Prado. Os compadres e as comadres de escravos: um balanço da produção historiográfica brasileira. In: SIMPÓSIO NACIONAL DE HISTÓRIA, 26.,2011, São Paulo, Anais... 2011. 
CAULFIELD, Sueann. Em defesa da honra. Moralidade, modernidade e nação no Rio de Janeiro (1918-1940). Campinas: Editora da Unicamp, 2000.

CASTRO, Hebe Mattos; RIOS, Ana Maria. Memórias do Cativeiro: família, trabalho e cidadania no pós-abolição. Rio de Janeiro: Civilização Brasileira, 2005.

Laços de família e direitos no final da escravidão In: ALENCASTRO, Luiz Felipe de. (Org.) História da vida privada no Brasil Império: a Corte e a modernidade. São Paulo: Companhia das Letras, 1997. p. 337-384.

Das cores do silêncio: os significados da liberdade no Sudeste escravista - Brasil, Século XIX. Rio de Janeiro: Arquivo Nacional, 1995

CHALHOUB, Sidney. Trabalho, lar e botequim. O cotidiano dos trabalhadores no Rio de Janeiro da Belle Epoque. Campinas: Editora da Unicamp, 2001.

Visões da liberdade. Uma história das últimas décadas da escravidão da corte. São Paulo: Companhia das Letras, 1990

COOPER, Frederick; HOLT, Thomas; SCOTT, Rebecca. Além da escravidão: investigacão sobre raç, trabalho, e cidadania. Rio de Janeiro: Civilização Brasileira, 2005.

COUCEIRO, Luiz Alberto. A disparada do burro e a cartilha do feitor: lógicas morais na construção de redes de sociabilidade entre escravos e livres nas fazendas do Sudeste, 1860-1888. Revista de Antropologia, São Paulo, USP, n.1 p.41-83, 2003.

ESTEVES, Martha de Abreu. Meninas perdidas. Os populares e o cotidiano do amor no Rio de Janeiro da Belle Epoque. Rio de Janeiro: Paz e Terra, 1989.

FERNANDES, Florestan. A integração do negro na sociedade de classes. São Paulo: Atica, 1978.

FLORENTINO, Manolo. Em costas negras. Uma históri do tráfico entre a África e o Rio de Janeiro. São Paulo: Companhia das Letras, 1997.

FRAGA FILHO, Walter. Encruzilhadas da liberdade. His tória de escravos e libertos na Bahia (1870-1910). Campinas: Editora da Unicamp: 2006

GRAHAM, Richard. Nos tumbeiros mais uma vez? O comércio interprovincial de escravos no Brasil. Revista AfroÁsia, Salvador, v.27, p.121-160, 2002.

HOFBAUER, Andreas. O conceito de 'raça' e o ideário do 'branqueamento' no século XIX - Bases ideológicas do - racismo brasileiro. Revista Teoria \& Pesquisa, São CarlosSP, jan./jul. 2003.

HOLLOWAY, Thomas. Imigrantes para o café: café e sociedade em São Paulo, 1886-1934. Rio de Janeiro: Paz e Terra, 1984.

The Middle Passage. Comparative Studies Press, 1978.
MONSMA, Karl. Desrespeito e violência: fazendeiros de café e trabalhadores negros no Oeste paulista, 1887-1914. Revista Anos 90, Porto Alegre, v.12, n.21/22, p. 103-149, jan./dez. 2005

MOTTA, José Flávio. Escravos daqui, dali e mais além: o tráfico interno de cativos em Constituição (Piracicaba), 1861-1880. Revista Brasileira de História, São Paulo, n.52, p.15-47, 2006.

Derradeiras transacões. O comércio de escravos $\overline{\text { nos } 18} 80$ (Areias, Piracicaba e Casa Branca, Província de São Paulo). Almanack Brasiliense, São Paulo, n.10, p.147163, nov. 2009

ORTIZ, Renato. Memória coletiva e sincretismo científico: as teorias raciais do século XIX. Cadernos CERU, São Paulo, n.17, p.13-35, 1982.

PORTES, Alejandro. Economic Sociology and the Sociology of Immigration: a conceptual overview. In: The Economic Sociology of Immigration. Essays on networks, Ethnicity and Entrepreneurship. New York: Russel Sage Foundation, 1995. p.1-41.

Social capital: its origins and applications in Modern Sociology. Annual Review of Sociology, v.24, p.124, 1998.

RAGO, Margareth. Do cabaré ao lar: a utopia da cidade disciplinar, Brasil, 1890-1930. Rio de Janeiro: Paz e Terra, 1985.

REIS, João José Gomes; SANTOS, Flávio dos; CARVALHO, Marcus Joaquim de. O alufá Rufino: tráfico, escravidão e liberdade no Atlântico negro (1822-1853). São Paulo: Companhia das Letras, 2010.

ROCHA, Cristiany Miranda. Histórias de famílias escravas. Campinas, Século XIX. Campinas: Editora da Unicamp, 2004

SÃO CARLOS. Prefeitura Municipal. Fundação Pró-Memória de São Carlos. Processo n.57, 1893. Caixa nº291.

SCHWARCZ, Lilia K. Moritz, O espetáculo das raças: cientistas, instituições e questão racial no Brasil, 18701930. São Paulo: Companhia das Letras, 1995.

SLENES, Robert W. Senhores e subalternos no Oeste paulista. In: ALENCASTRO, Luiz Felipe. História da vida privada no Brasil 2. Império: a corte e a modernidade nacional. São Paulo: Companhia das Letras, 1997. p. 233290.

Na senzala, uma flor. Esperancas e recordações na formacão da família escrava - Brasil, Sudeste, Século XIX. Rio de Janeiro: Nova Fronteira, 1999.

TRUZZI, Oswaldo. São Carlos: café e indústria, 18501950. São Carlos,SP: Edufscar, 2000

Redes em processos migratórios. Revista Tempo Social, São Paulo, v.20, n.1, p.199-218, 2008.

VANGELISTA, Chiara. Os braços da lavoura: imigrantes e "caipiras" na formação do mercado de trabalho paulista (1850-1930). São Paulo: Hucitec, 1991. 


\section{FAMILIAL SOCIABILITY AND LIBERTY: post- abolition interpersonal relations}

\author{
Rogério da Palma \\ Oswaldo Truzzi
}

According to the historiography about the end of slavery, the social ties constituted while still in captivity were essential to those liberated in the construction of a trajectory leading from slavery to liberty. Taking as a focus the municipality of São Carlos, this article analyzes the tensions present in the interpersonal relations woven between the Afro-Brazilian slaves, on one side, and the farmers and small, rural land-holders on the other, during the post-emancipation period. Through the close-reading of two police reports of the era, one can perceive that the moral codes which orient these sociabilities were (re)constructed, in part by the Afro-Brazillians, starting from the articulation of two lived experiences: the internal migration of slaves, which occurred during the final decades of slavery, and the process of redefinition of determined social hierarchies consolidated in the post-abolition era. These moral codes, in their turn, ended up delimiting a specific vision regarding familial sociability.

KEY-WorDS: Post-abolition. West São Paulo. Blacks. Coffee economy. Interpersonal relations.
SOCIABILITÉS FAMILIALES ET LIBERTÉ: les relations interpersonnelles dans la post-abolition

\author{
Rogério da Palma \\ Oswaldo Truzzi
}

Selon l'historiographie de la fin de l'esclavage, pour ceux qui ont été libéré, les liens sociaux établis alors qu'ils étaient encore en captivité ont joué un rôle fondamental dans l'élaboration de la trajectoire allant de l'esclavage à la liberté. En se concentrant sur la municipalité de Sao Carlos, cette étude analyse les tensions existantes dans les relations interpersonnelles construites entre les Noirs, d'une part, et les grands propriétaires terriens et petits propriétaires ruraux, d'autre part, au cours de la période postémancipation. Grâce à la lecture de deux enquêtes policières de l'époque on a pu relever que les codes moraux directeurs de ces sociabilités ont été (re)construits par les Afro-brésiliens à partir de l'articulation entre deux expériences vécues, la migration interne d'esclaves qui a eu lieu au cours des dernières décennies de l'esclavage et le processus de redéfinition de certaines hiérarchies sociales établi dans la période post-abolition. Ces codes moraux, à leur tour, ont fini par délimiter une vision spécifique des sociabilités familiales.

Mots-Clés: Post-abolition. Ouest de Sao Paulo. Noirs. Économie du café. Relations interpersonnelles.

\footnotetext{
Rogério da Palma - Doutorando em Sociologia na Universidade Federal de São Carlos - UFSCar, com estágio na Universidade de Michigan. Bolsista da FAPESP. Publicações recentes: As articulações entre intimidade e trabalho: a construção social de um mercado de trabalho livre no oeste paulista cafeeiro. Sociologias (UFRGS), v. 14, p. 224-251, 2012; Identidades e mercado de trabalho: uma análise do perfil étnico-racial e ocupacional dos latifúndios cafeeiros em São Carlos (1907). Locus (UFJF), v. 15, p. 91-110, 2009; Estrutura familiar entre imigrantes italianos nas fazendas cafeeiras de São Carlos (1907). In: LUCENA, Célia; CAMPOS, Maria Christina. (Org.). Questões ambientais e sociabilidades. São Paulo, 2008, p. 67-188.

Oswaldo Truzzi - Doutor em Ciências Sociais. Professor associado da UFSCar. nos Programas de Pós-Graduação em Ciências Sociais e Engenharia de Produção. Pesquisador do CNPq. Tem experiência na área de Sociologia, com ênfase em Sociologia das Migrações, das Organizações e do Trabalho, atuando principalmente nos seguintes temas: Sociologia das Migrações, História Social da Imigração, Sociologia do Trabalho e das Organizações. Dirige desde 2000 a Editora da Universidade Federal de São Carlos. Publicações recentes: Mudança de fronteiras étnicas e participação política de descendentes de imigrantes em São Paulo. Revista Brasileira de Ciências Sociais, v. 27, p. 135-151, 2012; Assimilação re-significada: Novas Interpretações de um Velho Conceito. Dados (Rio de Janeiro), v. 55, p. 517-553, 2012; Redes em processos migratórios. Tempo Social (USP. Impresso), v. 20, p. 199-218, 2008.
} 
